$\mathbf{R}_{\text {ESEARCH }} \mathbf{P}_{\text {APER }}$

FOOD SCIENCE

RESEARCH JOURNAL e ISSN-2230-9403 — Visit us : www. researchjournal.co.in Volume 9 | Issue 1 | April, 2018 | 112-116 DOI : $10.15740 /$ HAS/FSRJ/9.1/112-116

\title{
Preparation of basundi from buffalo milk blended with custard apple (Annona squamosa L.) pulp
}

\author{
D.N. Phalake, S.D. Chavan, R.R. Shelke, S.P. Nage and S.R. Shegokar
}

In present investigation Basundi was prepared from buffalo milk blended with different levels of custard apple pulp as control with $\mathrm{O} \%\left(\mathrm{~T}_{1}\right), 5 \%\left(\mathrm{~T}_{2}\right), 10 \%\left(\mathrm{~T}_{3}\right), 15\left(\mathrm{~T}_{4}\right)$ and $20\left(\mathrm{~T}_{5}\right)$. The results revealed that, fat, protein, Ash and total solid contents were normally decreased while total sugar was increased with increase in levels of custard apple pulp. For sensory evaluation the results revealed that overall acceptability scores obtained were 7.09, 7.53, 7.96, 7.19, and 6.92 for the treatment $\mathrm{T}_{1}, \mathrm{~T}_{2}, \mathrm{~T}_{3}, \mathrm{~T}_{4}$ and $\mathrm{T}_{5}$, respectively. The treatment $\mathrm{T}_{3}$ scored significantly highest scores for flavour, colour and appearance, consistency and overall acceptability which were found superior amongst all the treatments. The custard apple pulp prepared from all combinations of buffalo milk basundi was found acceptable. The cost of production per $\mathrm{kg}$ of custard apple basundi was slightly increased with increase in rate of addition of custard apple pulp percentage. i.e. Rs. $98.18\left(\mathrm{~T}_{1}\right)$, Rs. $104.78\left(\mathrm{~T}_{2}\right)$, Rs. $110.83\left(\mathrm{~T}_{3}\right)$, Rs. $116.4\left(\mathrm{~T}_{4}\right)$ and Rs. $121.53\left(\mathrm{~T}_{5}\right)$.

Key Words : Basundi, Buffalo milk, Custard apple, Chemical analysis, Sensory evaluation, Cost of production

How to cite this article : Phalake, D.N., Chavan, S.D., Shelke, R.R., Nage, S.P. and Shegokar, S.R. (2018). Preparation of basundi from buffalo milk blended with custard apple (Annona squamosa L.) pulp. Food Sci. Res. J., 9(1): 112-116, DOI : 10.15740/HAS/ FSRJ/9.1/112-116. 